\title{
Pulsed-wave doppler ultrasound in canine reproductive system - Part 1: technical
}

\section{aspects}

\author{
Ultrassonografia em modo Doppler pulsado no sistema reprodutor canino - Parte 1: aspectos \\ técnicos
}

Ecografía Doppler de onda pulsada en el aparato reproductor canino - Parte 1: aspectos técnicos

\author{
Camila Franco de Carvalho \\ ORCID: http://orcid.org/0000-0002-5233-6548 \\ Universidade Federal de Jataí, Brazil \\ E-mail: camilafcarvalho@gmail.com \\ Jéssica Ribeiro Magalhães \\ ORCID: http://orcid.org/0000-0001-8165-9365 \\ Universidade Federal de Jataí, Brazil \\ E-mail: jessicarmedvet@gmail.com \\ Andreia Moreira Martins \\ ORCID: http://orcid.org/0000-0002-8283-9779 \\ Universidade Federal de Jataí, Brazil \\ E-mail: andreia_dover@hotmail.com \\ Kyrla Cartynalle das Dores Silva Guimarães \\ ORCID: http://orcid.org/0000-0002-6194-1280 \\ Universidade Federal de Jataí, Brazil \\ E-mail: kynally83@hotmail.com \\ Reiner Silveira de Moraes \\ ORCID: http://orcid.org/0000-0002-1468-2968 \\ Universidade Federal de Jataí, Brazil \\ E-mail: rmoraes@ualberta.ca \\ Daniel Bartoli de Sousa \\ ORCID: http://orcid.org/0000-0003-3209-7911 \\ Universidade Federal de Jataí, Brazil \\ E-mail: daniel_bartoli_sousa@ufg.br \\ Andréia Vitor Couto do Amaral \\ ORCID: https://orcid.org/0000-0001-6406-2372 \\ Universidade Federal de Jataí, Brazil \\ E-mail: andreiavcvet@ufg.br
}

\begin{abstract}
The purpose of this article is to review the literature on the essential technical aspects of implementing the pulsed Doppler, as part of the teachings to their use in the diagnosis of changes in the canine reproductive system. A narrative review was carried out, using scientific articles, monographs, theses and dissertations published and available in online databases: Periodical Capes (Coordination for the Improvement of Higher Education Personnel), SciELO (Scientific Electronic Library Online) and Google Scholar, in addition to specific books on the topic. Twodimensional ultrasound has been widely used in medicine since 1942, leading to advancements in disease identification and subsequent prognosis. In terms of vascular assessment, Doppler ultrasound is used to evaluate the blood flow inside the vessel, its direction, and hemodynamic pattern. Among all types of Doppler ultrasound, the Color Doppler (CD), Power Doppler (PD), and the Pulsed-wave Doppler (PW) are commonly used in the identification of abnormalities through ultrasound flow imaging and the analysis of hemodynamic indices: peak systolic velocity (PSV), end diastolic velocity (EDV), resistance index (RI), and pulsatility index (PI). To accurately estimate these hemodynamic indices, however, it is essential to know the technical adjustments and parameters such as the pulse repetition frequency (PRF), size of the sample volume (Gate), angle of insonation, gain, baseline, and wall filter, which need to be corrected to avoid technician derive artifacts such as aliasing, signal absence, and mirror imaging. In medicine, the use of Doppler Mode in reproductive functions is already well established, but its use in veterinary medicine is still a subject of recent studies.
\end{abstract}

Keywords: Dog; Doppler effect; Resistance index; Spectral doppler; Ultrasound. 


\begin{abstract}
Resumo
O objetivo do trabalho é realizar uma revisão de literatura sobre os aspectos técnicos essenciais para execução do Doppler pulsado, como parte dos ensinamentos para sua utilização no diagnóstico das alterações do trato reprodutor canino. Realizou-se uma revisão narrativa, utilizando artigos científicos, monografias, teses e dissertações publicadas e disponíveis nas bases de dados online: Periódico Capes (Coordenação de Aperfeiçoamento de Pessoal de Nível Superior), SciELO (Scientific Electronic Library Online) e Google Acadêmico, além de livros específicos do tema. Desde 1942, a medicina experimenta evoluções na identificação de enfermidades e avanços para o prognóstico, advindas da crescente utilização do exame ultrassonográfico bidimensional. No que diz respeito à avaliação vascular, o Modo Doppler permite o conhecimento da presença de fluxo sanguíneo, sua direção e padrão hemodinâmico. Dentre as modalidades, destacam-se o Doppler colorido (CD), Doppler de amplitude (PD) e o Doppler espectral ou pulsado (PW), que permite a identificação de anormalidades por meio do espectro formado e pela análise dos índices hemodinâmicos: Velocidade de pico sistólico (VPS), Velocidade diastólica final (VED), Índices de resistividade (IR) e pulsatilidade (IP). O conhecimento dos ajustes técnicos é imprescindível para a correta obtenção dos índices e parâmetros como frequência de repetição de pulso (PRF), volume de amostra (Gate), ângulo de insonação, ganho, linha de base e filtro de parede devem ser corrigidos para evitar a formação de artefatos como aliasing, ausência de sinal e imagem em espelho. Na medicina, o uso do Modo Doppler nas funções reprodutivas já se encontra bem consolidado, mas na medicina veterinária as pesquisas ainda são recentes.
\end{abstract}

Palavras-chave: Cão; Doppler espectral; Efeito doppler; Índice de resistividade; Ultrassom.

\title{
Resumen
}

El objetivo del trabajo es realizar una revisión de la literatura sobre los aspectos técnicos esenciales para la ejecución del Doppler pulsado, como parte de las enseñanzas para su uso en el diagnóstico de alteraciones en el aparato reproductor canino. Se realizó una revisión narrativa, utilizando artículos científicos, monografías, tesis y disertaciones publicados y disponibles en bases de datos en línea: Periodical Capes (Coordinación para el Perfeccionamiento del Personal de Educación Superior), SciELO (Scientific Electronic Library Online) y Google Scholar, además libros específicos sobre el tema. Desde 1942, la medicina ha ido evolucionando en la identificación de enfermedades y avances en el pronóstico, derivados del creciente uso de la ecografía bidimensional. En cuanto a la evaluación vascular, el Modo Doppler permite conocer la presencia de flujo sanguíneo, su dirección y patrón hemodinámico. Entre las modalidades, destacamos el Doppler color (CD), el Doppler de amplitud (PD) y el Doppler espectral o pulsado (PW), que permite la identificación de anomalías a través del espectro formado y mediante el análisis de índices hemodinámicos: Velocidad de pico sistólico (SPV), velocidad diastólica final (VED), índices de resistividad (IR) y pulsatilidad (IP). El conocimiento de los ajustes técnicos es fundamental para la correcta obtención de índices y parámetros como frecuencia de repetición de pulsos (PRF), volumen de muestra (Gate), ángulo de insonación, ganancia, línea de base y filtro de pared deben corregirse para evitar la formación de artefactos como el aliasing, ausencia de señal e imagen especular. En medicina, el uso del modo Doppler en funciones reproductivas ya está bien establecido, pero la investigación en medicina veterinaria es aún reciente.

Palabras clave: Doppler espectral; Efecto doppler; Índice de resistividad; Perro; Ultrasonido.

\section{Introduction}

Recent in technological developments has facilitated the discovery and use of new diagnostic resources in medicine. Since the introduction of ultrasonic waves as a diagnostic tool in 1942, medicine has been evolving in the identification of diseases and improvements in prognosis. In fact, ultrasound has been become an essential tool in clinical practices, including veterinary medicine, as it adds dynamic measurement to the clinical examination and improves quality of daily medical care for patients (Carvalho \& Addad, 2009; Genc et al., 2016; Seoane et al., 2016; Gupta et al., 2019).

Among all types of ultrasounds, the B-mode (commonly referred to as "brightness mode" or two-dimensional) is used to evaluate the interaction between the ultrasonic wave and the various organic tissues through two-dimensional images on gray scale. However, B-mode presents limitations when used for vascular diagnostic evaluation, including failure to detect the presence of blood flow inside the vessel, its direction, and hemodynamic pattern. For this reason, the Doppler ultrasound (which measures sound waves that are reflected from moving objects, such as red blood cells) has become an essential tool for assessing hemodynamic conditions in patients (Carvalho et al., 2008; Carvalho \& Addad, 2009; Pellerito \& Polak, 2012).

The imaging of blood flow obtained by Doppler ultrasound can be presented mainly via: Color Doppler (CD) and Power/Amplitude Doppler (PD), which creates colored image for qualitative evaluation of the speed and direction of blood flow through the vessel; Continuous wave $(\mathrm{CW})$ and Pulsed-wave Doppler (PW), which creates images of the waveform 
morphology for quantitative analysis such as velocity as a function of time (Carvalho et al., 2008; Carvalho \& Addad, 2009; Jenderka \& Delorme, 2015; Matoon \& Nyland, 2015; Romualdo, 2015; Revzin et al., 2019).

The CD ultrasound was initially used in the first ultrasound devices for detection of blood flow, even at high speeds, but it was not able to discriminate depth and generate two-dimensional images, providing only spectral wavelengths. Through technological development, current devices use combination of real time B-mode and spectral wavelengths to generate images, making this modality widely used in cardiology (Jenderka \& Delorme, 2015; Matoon \& Nyland, 2015; Romualdo, 2015; Revzin et al., 2019; Oliveira et al., 2020).

The majority of modern ultrasound devices have the ability to map the movement of red blood cells, encoded in colored nuances using the $\mathrm{CD}$ and $\mathrm{PD}$ method. In the $\mathrm{CD}$ ultrasound, a colored image is created based on the flow direction in relation to the transducer, presenting images in blue (indicating the distance from the source) and red (indicating the approach from the source). These colors show the speed and direction of blood flow inside the vessel and vary depending on the intensity of the color displayed (Carvalho et al., 2008; Carvalho \& Addad, 2009; Roy et al., 2012).

In contrast, it is not possible to collect information on the blood flow direction with the Power Doppler ultrasound, as it only generates images with different shades of orange. However, Power Doppler has greater sensitivity in detecting smaller and slow flow, in addition to less risk of artifact formation due to the dependence of the angle formed by the transducer and the vessel analyzed (Carvalho et al., 2008; Carvalho \& Addad, 2009; Castelló et al., 2009; Matoon \& Nyland, 2015).

The PW ultrasound consists of the presentation of a waveform spectrum that can be used to distinguish arterial, venous, and turbulent flows, and it can measure quantitative parameters such as the speed variation along the cardiac cycle, vascular impedance and resistance. Thus, it is considered to be a resource of great utility in the detection and differentiation of physiological pathological flows (Carvalho et al., 2008; Paolinelli, 2013; Holen, 2014; Jenderka \& Delorme, 2015; Revzin et al., 2019).

There are several applications for the combined use of B-mode and Doppler in the veterinary clinical routine, including detection of shunts, arteriovenous malformations, thrombus research, etc. In addition to providing quantitative data that yields important information for a more accurate diagnosis, the PW ultrasound is recommended as the first option for imaging analysis of various diseases, including those related to the reproductive system, because it can be better than invasive and complex technologies that use ionizing radiation (Holen, 2014; Lee, 2014; Benacerraf et al., 2015; Negreiros et al., 2020).

Although the Doppler ultrasound has been recently used in veterinary medicine, the B-mode performed in the routine can be improved with further knowledge. In this sense, the purpose of this article is to review the literature on the essential technical aspects of implementing the pulsed Doppler, as part of the teachings to their use in the diagnosis of changes in the canine reproductive system.

\section{Methodology}

A narrative review was carried out using scientific articles, monographs, dissertations and theses published and available in online databases: Periodical Capes (Coordination for the Improvement of Higher Education Personnel), SciELO (Electronic Scientific Library Online) and Google Scholar, in addition to theme-specific books. According to the methodology cited by Pinto et al. (2021), studies that did not address the main theme under analysis were excluded, as well as articles with opinion that were not supported by research data.

For the organization of the review, the technical aspects of pulsed wave ultrasound were divided into: physical principles, processing and interpretation of spectral Doppler images, technical adjustments and main artifacts observed. To illustrate, photographs of ultrasound procedures performed on dogs of the Medical Clinic Department at the Veterinary Hospital of the Federal University of Jataí (HV/UFJ) were used. All procedures were carried out under previous signing the 
consent form of the tutor or responsible for the animal, following the protocols of the HV/UFJ and Ethics in Animal Experimentation (CEUA 008/2018).

\section{Technical aspects of Pulsed-Wave ultrasound}

\subsection{Physical principles - Doppler Effect}

When observing the change in the color of stars in the sky and relating it to changes in their speed and frequency in 1842, Christian Andreas Doppler did not know that his discovery would be used after a century as an instrument of great repercussion in the evolution of medicine. In 1845, Christoph Ballot proved the theory in the field of acoustics, and in 1848, Hippollyte Fizeau made the same observation with electromagnetic waves. After further observations and contributions from other physicists at the time, the "Doppler Effect" was established, also known as "Doppler-Fizeau Effect" or "Doppler-FizeauBallot Effect”, a physical phenomenon applicable to all existing waves (Schuster, 2007; Carvalho \& Addad, 2009; Romualdo, 2015).

The Doppler effect is characterized as the relative movement between a source originating from electromagnetic or sound waves and an observer or sensor, in which one of them being in motion causes changes in the frequency of the reflected waves. One can easily confirm this phenomenon by observing the increasing tone of an approaching car horn sound and its decrease when the car moves away, a fact caused by the compression or expansion of the sound waves (Carvalho et al., 2008; Romualdo, 2015; Kaunitz, 2016; Oglat et al., 2018).

When examining a blood vessel, there is a physical interaction between the waves emitted by the device transducer (stationary source) and the red blood cells in motion (moving source), which also act as reflecting bodies. As the red blood cells approach or move away from the original source, there are changes in the frequency of the reflected waves, i.e. smaller or longer wavelengths. If both the source and the observer were stationary, there would not be such changes in wavelengths, as can be seen in B-mode - Figure 1 (Carvalho \& Addad, 2009; Matoon \& Nyland, 2015; Oglat et al., 2018).

The ultrasound examination is based on pulses and echoes, and when emitting the wave, the transducer acts as a stationary source and the wave is related to the movement of red blood cells (moving source). This reflects the signal towards the transducer and suggests that the Doppler Effect occurs twice in the same interaction, and this situation is called "displacement of the Doppler frequency (DF), which can be calculated according to the following equation: $D F=2 x$ Fo $x$ $V / C$, where $F o$ is the frequency transmitted by the probe, $\mathrm{V}$ is the speed of blood flow, and $\mathrm{C}$ is the speed of sound in soft tissues - constant of $1.540 \mathrm{~m} / \mathrm{s}$ (Carvalho et al., 2008; Pellerito \& Polak, 2012; Matoon \& Nyland, 2015) . However, it is known that the Doppler signal is influenced by the angle between the sound beam and the direction of blood flow (being greater when both are parallel and less when they are perpendicular) and, thus, used to adjust the equation as follows: $D F=2$ $\times F o \times V \times \cos \theta / C$, when $\theta$ is the angle of insonation (Carvalho et al., 2008; Matoon \& Nyland, 2015; Romualdo, 2015). 
Figure 1. Physical interaction between the waves emitted by the transducer (stationary source and reflective bodies. A immobile reflective body; B and C - mobile reflective bodies (red blood cells), moving towards the transducer (B) or moving away $(\mathrm{C})$ and causing effects on the reflected wave.

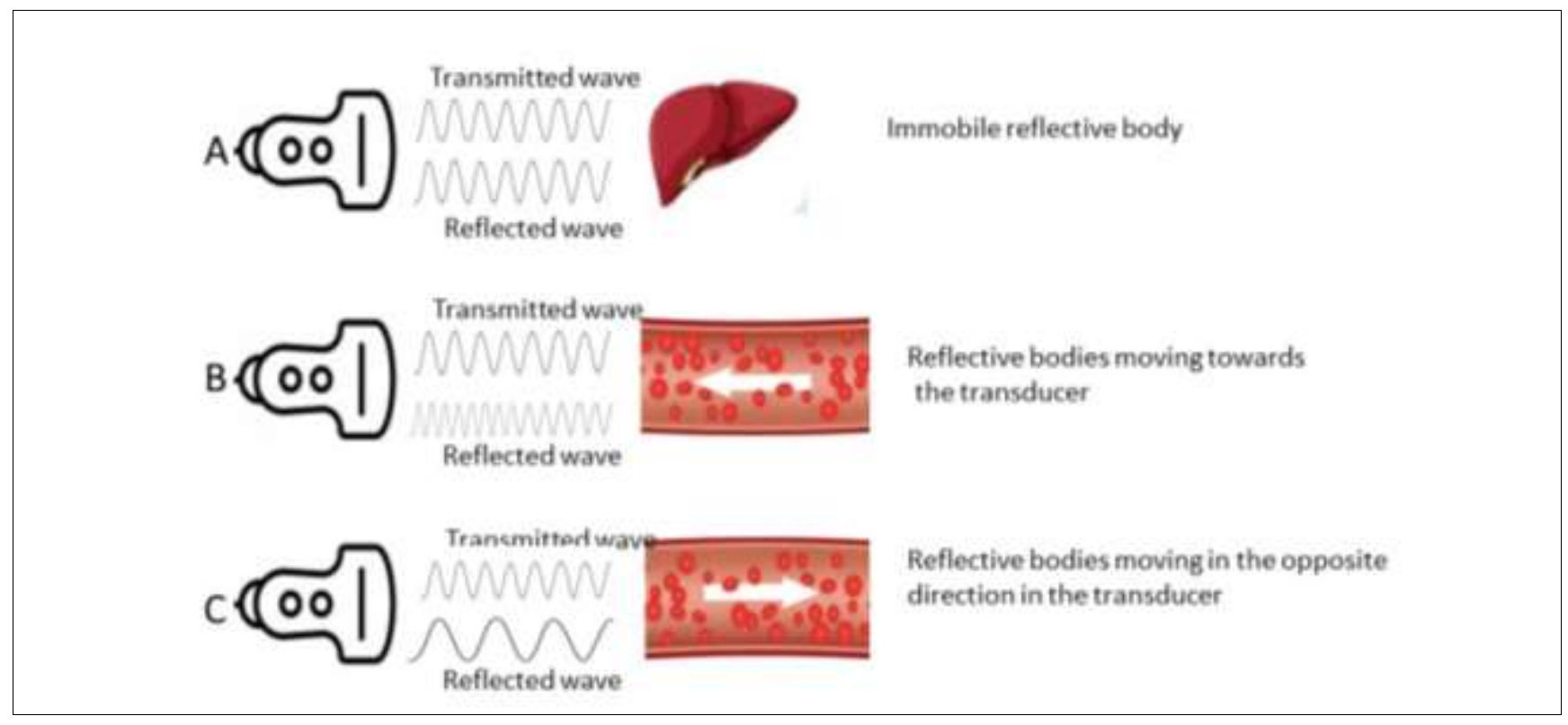

Source: Adapted from Carvalho \& Addad (2009).

During the examination, it is essential to observe and correct the angle of insonation because values greater than $60^{\circ}$ (acceptable upper limit) cause errors in the estimation of speed, due to large changes in the $\cos \theta$ values. In practice, the smaller angles reduce the errors and result in obtaining better estimates (Matoon \& Nyland, 2015; Romualdo, 2015; Revzin et al., 2019).

\subsection{Processing and interpretation of Doppler spectral images}

There are three ways of displaying the images obtained during the ultrasound examination. The first image is displayed in B-mode, using a gray scale. When pressing the Pulsed-Wave Doppler key, a double scan will be performed, and images will be displayed in Doppler and B-mode, referred to as Doppler Duplex ultrasound. The Doppler Duplex mode can also be obtained as the combination of B-mode with CD or PD. However, most available devices have the ability to perform a Triplex ultrasound, which is a combination of the Doppler, B-mode, and PW Doppler - Figure 2 (Carvalho et al., 2008; Holen, 2014; Romualdo, 2015).

During the examination, the sound is transmitted in pulses and the echoes are captured at different speeds and angles, representing the different changes in frequency. In turn, these are demodulated, processed, and displayed in the form of graphs that represent the speed variations according to time. These changes in frequency are also noticeable to the human ear and distinguishable between arterial, venous, and turbulent flow (Carvalho \& Addad, 2009; Oglat et al., 2018; Revzin et al., 2019).

When evaluating the wavelength spectrum, essential information can be obtained to evaluate the hemodynamic condition of the patient, such as the evaluation of the spectral morphology, the determination of absolute velocities, and vascular characteristics such as resistance, pulsatility, and acceleration (Revzin et al., 2019). 
Figure 2. Duplex image (Mode B and Color Doppler Mode) using multifrequency linear transducer (5 to $12 \mathrm{MHz}$ ) of liver vessels of mixed breed adult dog (A); Triplex image (Mode B, Power Doppler Mode and Spectral Doppler) using a multifrequency linear transducer ( 5 to $12 \mathrm{MHz}$ ) of the uterine artery of a mixed breed adult dog (B).

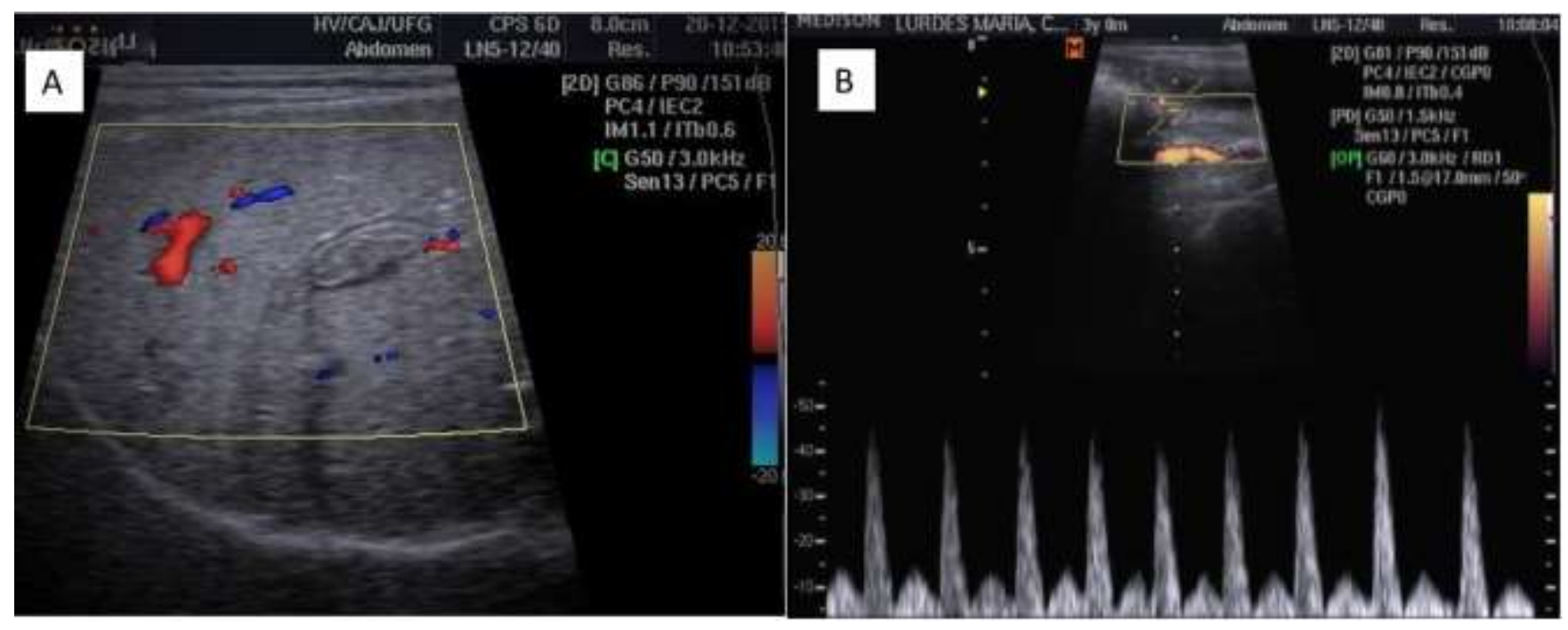

Source: Authors.

Regarding the velocities, it is possible to observe that when a cardiac contraction occurs, the blood reaches a maximum value, called peak systolic velocity (PSV), and then, it reaches to a minimum - end diastolic velocity (EDV) until the moment of a new contraction. These values represent the hemodynamic indices and are used in quantitative assessment of the blood flow behavior inside the vessel. In addition to the abovementioned indices, it is possible to establish mathematical relationships between them to estimate the resistance index (RI) and pulsatility index (PI), which make it possible to better understand the compliance of the vascular system being examined (Carvalho et al., 2008; Holen, 2014; Matoon \& Nyland, 2015).

The RI and PI are automatically calculated by the device software, highlighting the spectral area to be analyzed. However, it is also possible to estimate these indices according to the following equations: $R I=P S V-E D V / P S V ; P I=P S V-$ $E D V / V m$, where $V m$ is the mean velocity, also provided by the software. These indexes are used as an aid in the identification of stenosis and thrombosis, and to better understand the condition of tissue perfusion, as physiological situations such as pregnancy and pathological situations (e.g. pyometra) that require high metabolism tend to have lower RI - Figure 3 (Romualdo, 2015; Carvalho \& Addad, 2009; Revzin et al., 2019). 
Figure 3. Triplex Doppler image of mixed breed female uterine artery, using multifrequency linear transducer (5 to $12 \mathrm{MHz}$ ), demonstrating spectrum and hemodynamic indexes (Vel A = systolic peak velocity; Vel $\mathrm{B}=$ final diastolic velocity; IR = resistivity index; A / B = relationship between speed values).

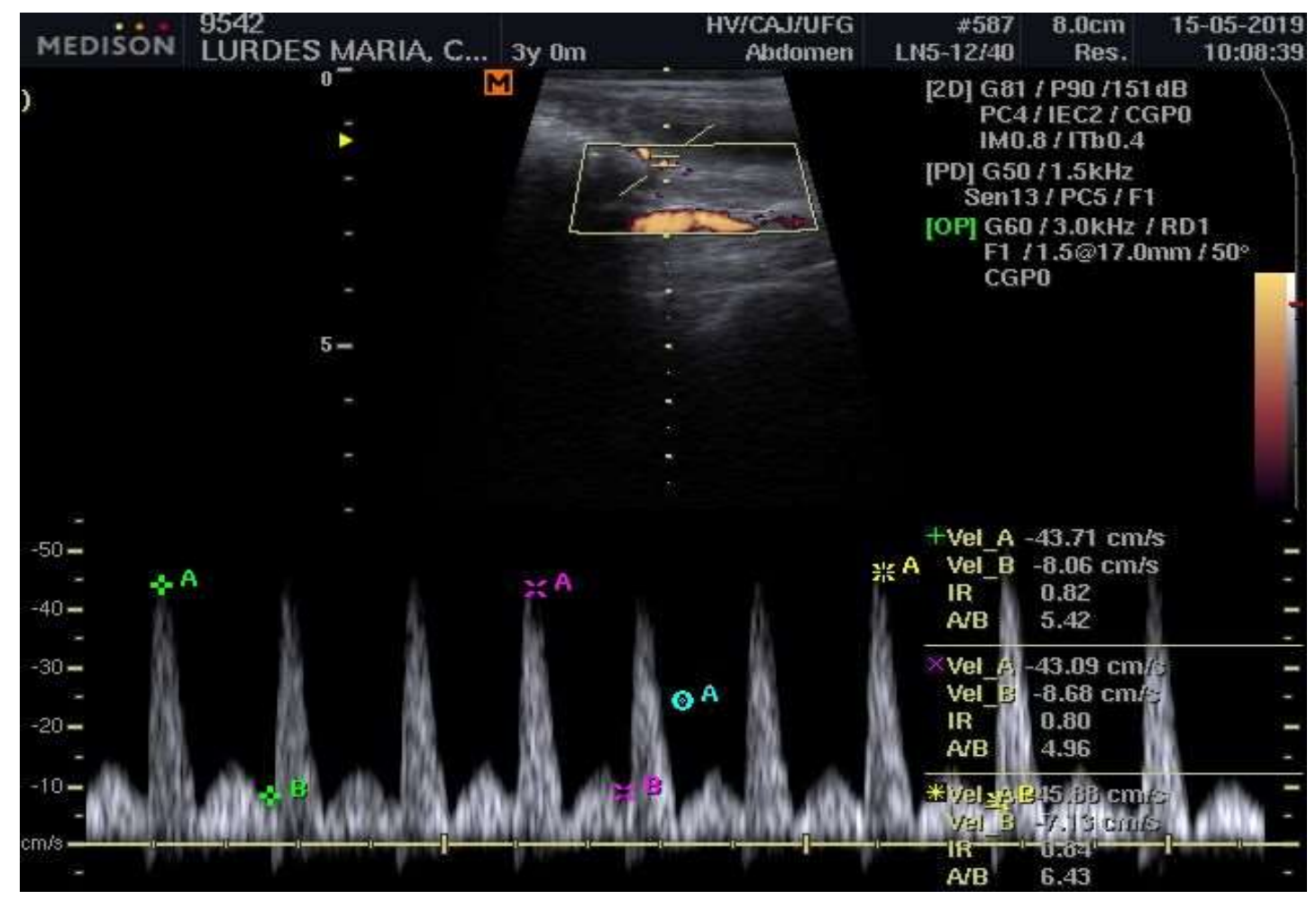

Source: Authors.

\subsection{Technical adjustments}

When starting the exam, some technical adjustments are necessary to adapt the range of variations presented by the patients. Thus, it is essential that the image obtained in B-mode is correctly presented, making sure that the default settings of the transducer are adequate and parameters such as frequency, gain, and focus are correctly adjusted, and this allows for proper visualization of the vessel to be analyzed and enabling the detection of existing morphological changes (Carvalho et al., 2008; Romualdo, 2015; Jenderka \& Delorme, 2015).

Similarly, when performing the Triplex Doppler ultrasound, the Color Doppler mode must use the correct angle, frequency, gain, and size of sample volume. Using the smallest possible sample volume size is recommended in order to optimize the image resolution. It is important to highlight that after selecting the PW option, it is not possible to make adjustments in B-mode or CD if they are not properly presented, leading to an incorrect wavelength spectrum (Carvalho \& Addad, 2009; Lee, 2014; Jenderka \& Delorme, 2015; Revzin et al., 2019).

\subsubsection{Frequency of pulse repetition or velocity scale}

Pulse repetition frequency determines the number of ultrasound pulses emitted by the transducer over a designated period of time. In turn, this is used to define the speed limits that can be captured without the formation of artifacts and must be adjusted in accordance with the expected speed in each vessel, i.e. adapting low values of PRF in reduced flow and vice versa (Holen, 2014; Jenderka \& Delorme, 2015; Romualdo, 2015; Revzin et al., 2019). In some equipment, the PRF can be presented as speed and the correct adjustment avoids the formation of artifacts and errors of acquisition and interpretation of the spectra. 


\subsubsection{Baseline}

The baseline adjusts the spectral point at which no Doppler frequency shift is observed, that is, the speed corresponds to zero and in addition to the PRF, it must be correctly adjusted so that the spectral curve fills the graph properly. However, in some cases, adjusting the baseline allows for eliminating artifacts without the need to increase the PRF - Figure 4 (Jenderka \& Delorme, 2015; Romualdo, 2015; Revzin et al., 2019).

\subsubsection{Gain}

The adjustment in gain allows for regulating the amplification of the received signal and avoiding the presence of falsely detected echoes that cause unnecessary noise in the image, i.e. showing Doppler signals where there is no blood flow and blurry image. Consequently, this leads to incorrect estimations of speed if the detection mode is performed automatically by the device (Carvalho \& Addad, 2009; Jenderka \& Delorme, 2015; Romualdo, 2015; Revzin et al., 2019).

\subsubsection{Wall filter}

The correct adjustment of the wall filter prevents very small speeds (resulting from the movement of the patient) from interfering with the acquisition of the spectrum and cause "noise" above or below the baseline. However, care must be taken so that the filter is not excessively enlarged and subsequent fluxes with low speed are not detected (Jenderka \& Delorme, 2015; Revzin et al., 2019).

\subsubsection{Gate}

Also known as sample or aliquot volume, it determines how much of the flow throughout a vessel cross-section will contribute to the Doppler measurement. The operator can choose the entire vessel area in cases of measurements of total flow volume or just the central part in vessels with slower flow, where speeds are higher and more accurate. The latter method is recommended for the majority of vessels studied (Carvalho \& Addad, 2009; Castelló et al., 2009; Paolinelli, 2013; Holen, 2014; Jenderka \& Delorme, 2015; Revzin et al., 2019).

\subsubsection{Angle}

The Doppler angle, as previously mentioned, must not exceed $60^{\circ}$, so that there are no significant changes and erroneous results in determining the speed. It must also always be adjusted and properly positioned in the direction of flow. In some devices, the adjustment can be done manually during the examination (Carvalho \& Addad, 2009; Matoon \& Nyland, 2015; Revzin et al., 2019).

\subsection{Main artifacts observed}

\subsubsection{Aliasing}

The aliasing phenomenon, also known as range ambiguity, occurs when the blood velocity is higher than the frequency of the signal reflected in the Doppler shift, that is, the PRF is at low values for the flow to be analyzed. The upper limit of the spectrum is fragmented and is shown below the baseline, resulting in inability to perform measurements properly Figure 4. To correct this phenomenon, it is recommended that either the PRF values be increased and/or the baseline is reduced (Carvalho \& Addad, 2009; Holen, 2014; Revzin et al., 2019). 
Figure 4. Arterial spectral tracing of an adult mixed breed female dog, using a $7.5 \mathrm{MHz}$ linear transducer demonstrated aliasing artefate (white arrows) caused by the baseline positioning (A). Corrected spectral tracing after repositioning the baseline, without modifying the PRF (B).

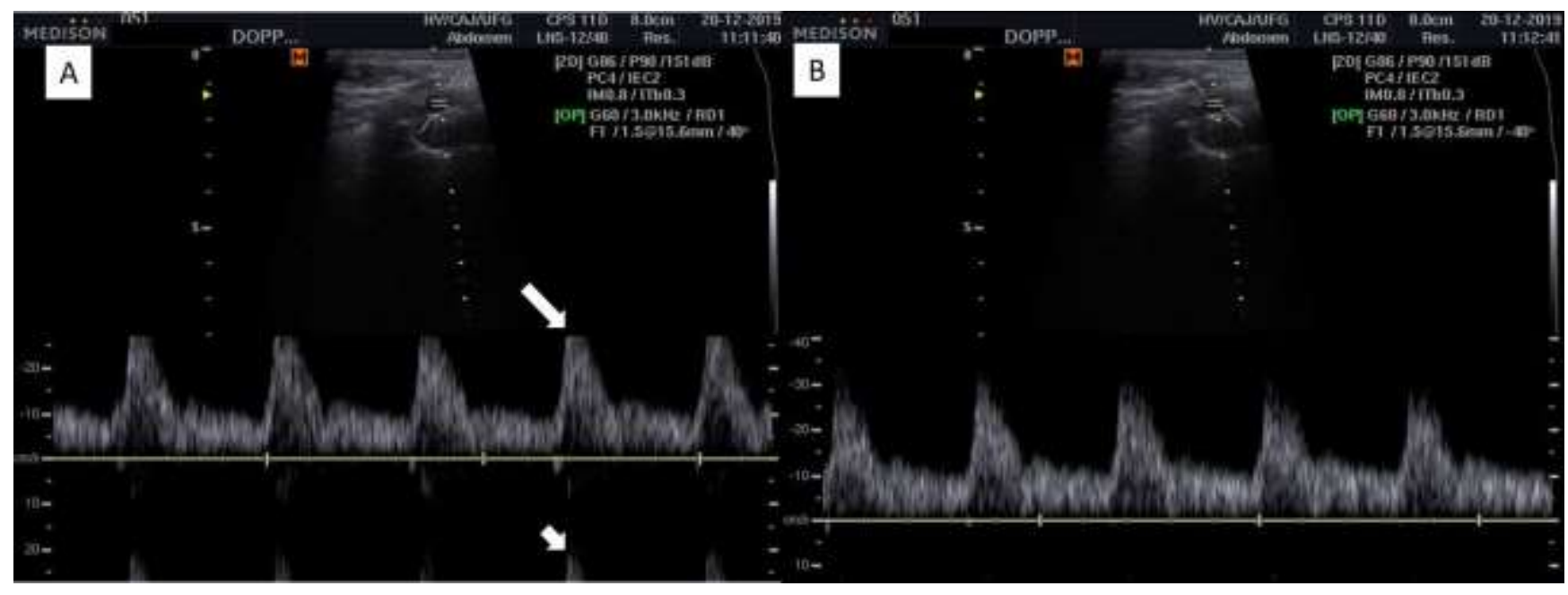

Source: Authors.

\subsubsection{Absence of signal}

If no image is generated when pressing the key to start the ultrasound, it is necessary to observe whether the angle of insonation between the sound beam and the vessel is near $90^{\circ}$, indicating that both are perpendicular to each other. The operator must then scan at another angle so that the signal is formed (Carvalho \& Addad, 2009; Castelló et al., 2009; Paolinelli, 2013; Holen, 2014; Jenderka \& Delorme, 2015; Romualdo, 2015; Revzin et al., 2019).

\subsubsection{Mirror image}

Like the B-mode, the mirror artifact can also occur during the formation of the Doppler spectrum, as the same spectrum is visible both above and below the baseline. The mirror artifact can be removed by reducing the gain of the Doppler mode and the sample volume (Carvalho \& Addad, 2009; Jenderka \& Delorme, 2015; Romualdo, 2015; Revzin et al., 2019).

\section{Final Considerations}

Doppler ultrasonography is an excellent diagnostic test, but some factors are necessary to increase its adoption in clinical practices. This includes complete mastery of the technique, which involves the veterinarian's time and dedication to establish and standardize protocols for the proper visualization of the vessels and correct formations of waves (angle of insonation), thus avoiding interference and erroneous data collection.

Currently, there is a great diversity of ultrasound devices that present both the Doppler and B-Mode simultaneously and, thus, are more cost accessible to most veterinary clinics. Although some studies have evaluated the use of these devices on reproductive examination, further studies are needed to better understand the diversity existing between the animal species (i.e. different breeds) and whether subclinical systemic diseases could cause hemodynamic changes in the reproductive system. These results also highlight the important of its use in academia because, similar to the human species, the Doppler ultrasound exam has shown great potential to provide greater diagnostic accuracy in the several reproductive diseases in dogs, as well as improving the reproductive status in herds.

Based on the similarity with human medicine, new studies can be developed, as an example of the evaluation of the placental tissue, and consequently its direct relationship with fetal health; as well as which systemic diseases can trigger 
reflexes in the perfusion of the reproductive system and so, affect the fertility of both female and male. There is still much to be studied about pulsed Doppler and its contributions to veterinary medicine. Moreover, research involving other organs and systems might be able to collaborate for the early detection of diseases and, therefore provide greater longevity to animals.

\section{References}

Benacerraf, B. R., Abuhamad, A. Z., Bromley, B., Goldstein SR., Groszmann, Y., Shipp, T. D. \& Timor-Tritsch, I. E. (2015). Consider ultrasound first for imaging the female pelvis. Am J Obstet Gynecol,_212(4), 450-455. Doi: 10.1016/j.ajog.2015.02.015.

Carvalho, C. F. \& Addad, C. A. (2009). Modos de Processamento da Imagem Doppler. In C. F. Carvalho (Ed), Ultrassonografia Doppler em Pequenos Animais (1st ed., pp. 7-15). Roca.

Carvalho, C. F., Chammas, M. C. \& Cerri, G. G. (2008). Princípios físicos do Doppler em ultra-sonografia. Ciência Rural, 38, 872-879. Doi:10.1590/s010384782008000300047.

Castelló, C. M., Bragato, N., Martins, I., Santos, T. V. \& Borges, N. C. (2015). Ultrassonografia doppler colorido e doppler espectral para o estudo de pequenos fluxos. Enciclopédia Biosfera, 11(22), 2691-2713. Doi: http://dx.doi.org/10.18677/Enciclopedia_Biosfera_2015_235.

Genc, A., Ryk, M., Suwała, M., Żurakowska, T, \& Kosiak, W. (2016). Ultrasound imaging in the general practitioner's office - a literature review. Journal of Ultrasonography, 16(64), 78-86. Doi: 10.15557/JoU.2016.0008.

Gupta, P., Lyons, S. \& Hedgire, S. (2019). Ultrasound imaging of the arterial system. Cardiovasc Diagn Ther, 9(Suppl 1), S2-S13. Doi: http://dx.doi.org/10.21037/cdt.2019.02.05.

Holen, J. (2014). Introduction to Vascular Ultrasonography. Radiology, 154. Doi:10.1148/radiology.154.2.442.

Jenderka, K. V. \& Delorme, S. (2015). Verfahren der Dopplersonographie. Radiologe, 55, 593-610. Doi:10.1007/s00117-015-2869-x.

Kaunitz, J. D. (2016). The Doppler Effect: A Century from Red Shift to Red Spot. Dig Dis Sci, 61(2):340-341. Doi: 10.1007/s10620-015-3998-9.

Lee, W. (2014). General principles of carotid Doppler ultrasonography. Ultrasonography, 33(1), 11-17. Doi: 10.14366/usg.13018.

Matoon, J. S. \& Nyland, T. G. (2015). Ovaries and uterus. In J. S. Matoon. \& T. G. Nyland (Eds.), Small animal diagnostic ultrasound (3 ${ }^{\text {rd }}$ ed., pp. 634-654). WB Saunders.

Negreiros, M. P. M. de., Seugling, G. H. de F., Almeida, A. B. M. de, Hidalgo, M. M. T., Martins, M. I. M., Blaschi, W. \& Barreiros, T. R. R. (2020). Influence of nutritional and ovarian parameters on pregnancy rates of Nelore cows artificially inseminated at fixed time. Research, Society and Development, 9(9), e907998091. Doi: https://doi.org/10.33448/rsd-v9i9.8091.

Oglat, A. A., Matjafri, M. Z., Suardi, N., Oqlat, M. A., Abdelrahman, M. A. \& Oqlat, A. A. (2018). A review of medical doppler ultrasonography of blood flow in general and especially in common carotid artery. J Med Ultrasound, 26(1), 3-13. Doi: 10.4103/JMU.JMU_11_17.

Oliveira, M. F. de., Vilar, A. M. A., \& Silvino, Z. R. (2020). Applicability of portable ultrasound for central venous access in critical neonates: scoping review. Research, Society and Development, 9(8), e744986495. Doi: https://doi.org/10.33448/rsd-v9i8.6495.

Paolinelli, P. (2013). Principios físicos e indicaciones clínicas del ultrasonido doppler. Rev Med Clin Condes, 24, 139-148. Doi: 10.1016/S0716$8640(13) 70139-1$.

Pellerito, J. S. \& Polak, J. F. (2012). Basic Concepts of Doppler Frequency Spectrum Analisis and Ultrasound Blood Flow Imaging. In P. Pellerito (Ed.), Introduction to vascular ultrassonography ( $6^{\text {th }}$ ed., pp. 52-73). Elsevier.

Pinto, R. B. B., Ribeiro, K. C., da Silva, M. F., Regalin, D., Meirelles-Bartoli, R. B. \& Amaral, A. V. C. do. (2021). Main anesthetic blocks for eye surgery in dogs and cats. Research, Society and Development, 10(3), 1-8. Doi: https://doi.org/10.33448/rsd-v10i3.13719.

Revzin, M. V., Imanzadeh, A., Menias, C., Pourjabbar, S., Mustafa, A., Nezami, N., Spektor, M. \& Pellerito, J. S. (2019). Optimizing Image Quality When Evaluating Blood Flow at Doppler US: A Tutorial. RadioGraphics, 39, 1501-1523. Doi: https://doi.org/10.1148/rg.2019180055.

Romualdo, A. P. (2014). Ajustes de aparelho. In A. P. Romualdo (Ed.), Doppler sem Segredos (1st ed., pp. 17-28). Elsevier.

Roy, H. S.; Zuo, G.; Luo, Z.; Wu, H.; Krupka, T. M.; Ran, H.; Li, P.; Sun, Y.; Wang, Z.; Zhengy, Y. (2012). Direct and Doppler angle-independent measurement of blood flow velocity in small-diameter vessels ultrasound microbubbles. Clinical Imaging, 36(5), 577-583.

Schuster, P. M. (2007). Revolucionário e ainda assim desconhecido! Rev. Bras. Ensino Fís., 29(3), 465-470.

Seoane, M. P. R., Garcia, D. A. A. \& Froes, T. R. (2016). A história da ultrassonografia veterinária em pequenos animais. Archives of Veterinary Science, 16(1), 54-61. Doi: http://dx.doi.org/10.5380/avs.v16i1.17646. 